\title{
THE SAYINGS ON CONFESSING AND DENYING JESUS IN Q 12:8-9 AND MARK 8:38
}

\author{
Henk Jan de Jonge \\ University of Leiden \\ (Leiden, the Netherlands)
}

Luke 12:8-9 (par. Matt 10:32-33) and Mark 8:38 form an undeniable cornerstone of any reconstruction of the early history of Christology. In these related passages Jesus speaks about the coming Son of Man in the third person singular without explicitly identifying himself with him. The discussion of these verses often entails the issue whether the words in question can be traced back, in one form or another, to the historical Jesus. The question was answered affirmatively by such exegetes as R. Bultmann and $\mathrm{H}$. Tödt, ${ }^{1}$ but negatively by E. Käsemann ${ }^{2}$ and P. Vielhauer. ${ }^{3}$ According to Käsemann the saying on confessing and denying is an example of the prophetic genre of the "rules of sacred law"; this genre is the creation of early Christian prophets and a product therefore of the early church's prophetic activity.

Q 12:8-9 and Mark 8:38 can only be construed to be separate witnesses to an earlier, traditional saying in which Jesus refers to the Son of Man as a distinct person if, firstly, Mark 8:38 can be

${ }^{1}$ R. Bultmann, Die Geschichte der synoptischen Tradition (Göttingen 1958'), p. 163: Mark 8:38 and Luke 12:8-9 represent "primäre Überlieferung. Aus ihnen spricht das prophetische Selbstbewusstsein Jesu; irgend weichen spezifisch christlichen Klang haben sie nicht. Auch ist hier zu betonen, dass einige Menschensohnworte offenbar keine christlichen Bildungen, sondern primäre Überlieferungen sind, so das eben genannte Wort Mk 8,38 bzw. Lk 12,8f." H. E. Tödt, Der Menschensohn in der synoptischen Überlieferung (Gütersloh 1963'), p. 206: Luke 12:8-9 (par. Matt 10:32-33) and Mark 8:38 par. belong to those sayings "die bei vorsichtiger Kritik als authentische Sprüche Jesu gelten dürfen."

${ }^{2}$ E. Käsemann, "Sätze heiligen Rechtes im Neuen Testament," NTS 1 (1954/55), pp. 248-260; reprinted in idem, Exegetische Versuche und Besinnungen, 2 vols. (Göttingen $1964^{3}$ ), Vol. 2, pp. 69-82.

${ }^{3}$ P. Vielhauer, "Jesus und der Menschensohn: Zur Diskussion mit Heinz Eduard Tödt und Eduard Schweizer," ZThK 60 (1963), pp. 133-177, reprinted in idem, Aufsätze zum Neuen Testament (Munich 1965), pp. 92-140. See H. T. Fleddermann, Mark and Q. A Study of the Overlap Texts, BEThL 122 (Louvain 1995), p. 149. 
shown to be independent of Q 12:8-9 and, secondly, Luke 12:9 can be shown to be independent of Mark 8:38. But the independence of Mark 8:38 over against $Q 12: 8-9$ as well as that of Luke 12:9 over against Mark 8:38 can be called into question. If, for instance, there are good reasons to assume that the phrase ov viò

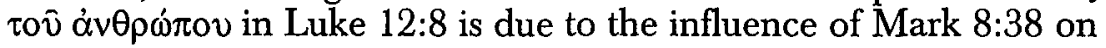
Luke's redaction of $Q$ 12:8-9, the phrase can no longer be ascribed to $Q$. In that case Q 12:8-9 is not a witness to a saying of Jesus about the Son of Man at all, let alone about the Son of Man as a distinct person. But if Q 12:8 (and 12:9, see below) did contain the

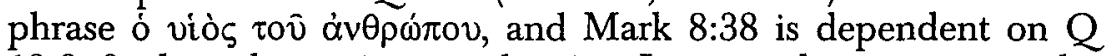
$12: 8-9$, then the saying on denying Jesus no longer retains the double attestation.

In the following pages it is our intention, therefore, to address two questions: (1) Is Luke's rewriting of $Q$ 12:8-9 dependent on Mark? and (2) Is Mark 8:38 dependent on Q 12:8-9?

In order to assess the literary relationship between Mark 8:38 and $Q$ 12:8-9 it will first be necessary to try to recover the common source (Q) of Luke 12:8-9 and Matt 10:32-33. Any attempt at reconstructing $Q$ remains, of course, a hazardous enterprise. This applies also to $Q$ 12:8-9. Yet the difficulties are perhaps somewhat less here than in many other cases. First, let us compare Matt 10:32-33 and Luke 12:8-9. (See the table on the facing page.)

${ }^{4}$ The Greek text is that of Synopsis quattuor evangeliorum, ed. K. Aland (Stuttgart $1988^{13}$ ), which is identical with that of $\mathrm{N}-\mathrm{A}^{26.27}$. There is a considerable amount of textual variation, both in Matthew and in Luke. But the text of N-A ${ }^{26.27}$ seems to be acceptable, except for the bracketed article in Matthew, both in v. 32 and v. 33. It should probably be omitted in both cases. See the note appended to this article. 
Matt 10:32-33

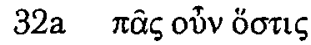

ó

$\ddot{\varepsilon} \mu \pi \rho \circ \sigma \theta \varepsilon v \tau \hat{\omega} v \dot{\alpha} v \theta \rho \omega \dot{\alpha} \omega \omega v$,

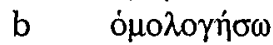

кóyó

غ่v $a \dot{\tau} \tau \hat{\omega}$

$\ddot{\varepsilon} \mu \pi \rho \circ \sigma \theta \varepsilon v$

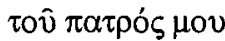

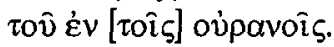

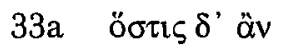

$\dot{\alpha} \rho v \eta \dot{\sigma} \sigma \tau \alpha i \dot{\mu} \mu \varepsilon$

$\ddot{\varepsilon} \mu \pi \rho \circ \sigma \theta \varepsilon v$

$\tau \hat{\omega} v \dot{\alpha} v \theta \rho \omega \dot{\pi} \pi \omega v$,

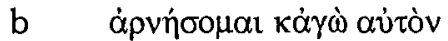

$\ddot{\varepsilon} \mu \pi \rho \circ \sigma \theta \varepsilon v$

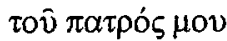

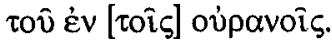

Luke 12:8-9

8a $\lambda \varepsilon \dot{\gamma} \omega \delta \dot{\varepsilon} \dot{v} \mu \mathrm{i} v$,

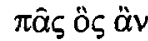

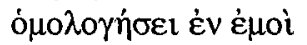
$\ddot{\varepsilon} \mu \pi \rho \circ \sigma \theta \varepsilon v \tau \tilde{\omega} v \dot{\alpha} v \theta \rho \omega \dot{\pi} \pi \omega v$,

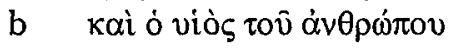
ó

$\dot{\varepsilon} v \alpha \dot{\tau} \tau \hat{\varphi}$ $\ddot{\varepsilon} \mu \pi \rho \circ \sigma \theta \varepsilon v$

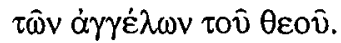

$9 \mathrm{a} \quad$ ó $\delta \dot{\varepsilon}$

$\dot{\alpha} \rho \vee \eta \sigma \alpha ́ \mu \varepsilon v o ́ \varsigma \mu \varepsilon$

غ́vómıov

$\tau \hat{\omega} v \dot{\alpha} v \theta \rho \omega \dot{\pi} \pi \omega v$,

b $\quad \dot{\pi} \pi \alpha v \eta \theta \dot{\eta} \sigma \varepsilon \tau \alpha \mathbf{l}$

غ̇vต́rıov

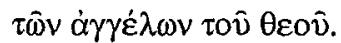

A few brief remarks on Matthew's and Luke's contributions to their redactional shape of these passages and on the underlying text of $Q$ must suffice.

In Luke 12:8a, $\lambda \dot{\varepsilon} \gamma \omega \delta \dot{\varepsilon} \dot{v} \mu \hat{\imath} v$ is probably Luke's addition to the text of $Q$. Within Luke 12:2-10 a new section begins at v. 8a. Luke marks the transition and the new beginning by inserting the prepositive formula $\lambda \dot{\varepsilon} \gamma \omega \delta \dot{\varepsilon} \dot{v} \mu \bar{\imath} v$, just as he did in $12: 4 \mathrm{a}$ and in $11: 9 .^{5}$ Matthew's oṽv (v. 32a), however, is no less redactional.

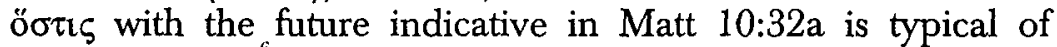
Matthew's diction. ${ }^{6}$ On the other hand, of twenty instances of ô $\varsigma$ äv

\footnotetext{
${ }^{5}$ F. Neirynck, "Recent Developments in the Study of Q," in idem, Evangelica, 2 vols., BEThL 60 \& 99 (Louvain 1982-1991), Vol. 2 (BEThL 99), pp. 409-464; see especially Neirynck's "Excursus: The $\lambda \dot{\gamma} \gamma \omega$ v่ $\mu i ̂ v$ Formula," pp. 436-449. On Luke 12:9, see p. 442. Contra R. Pesch, "Über die Autorität Jesu. Eine Rückfrage anhand des Bekenner- und Verleugnerspruchs Lk 12,8f par," in Die Kirche des Anfangs. Für Heinz Schürmann, edd. R. Schnackenburg, J. Ernst, and J. Wanke (Freiburg/Basel/Vienna 1978), pp. 25-55, see pp. 30-33. On $\lambda \dot{\gamma} \gamma \omega$ ú $\mu \hat{\imath} v$ in Luke 12:8, see also below.

${ }^{6}$ Pesch, "Autorität," p. 28; R. H. Gundry, Matthew. A Commentary on his Literary and Theological Art (Grand Rapids 1982), p. 198.
} 
occurring in Luke, at least ten were taken over from his written sources Mark (7 times) and Q (3 times). Only 3 times is ö $̧$ öv in Luke due to Lucan redaction of Marcan material. Obviously, Luke entertained no objections to taking over ôs äv from his sources. He probably did so also in 12:8 and 9 .

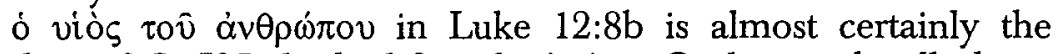
reading of $Q$. If Luke had found káró in $Q$, he can hardly have

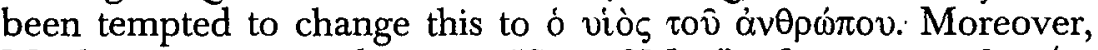
Matthew sometimes changes a "Son of Man" reference to a first (or third) person pronoun referring to Jesus since in his (Matthew's) view Jesus and the Son of Man were one and the same person: Matt 5:11 par. Q 6:22; Matt 16:21 par. Mark 8:31.

Luke 12:8 says that if people acknowledge Jesus before others, the Son of Man will acknowledge them "before the angels of God," whereas Matthew 10:32 says that Jesus will acknowledge them "before my Father in heaven." Now it is certain that Matthew's "my Father in heaven" is redactional. ${ }^{8}$ But what was the underlying reading of $Q$ ? Did $Q$ read what we have in Luke, "before the angels of God," or did it contain only a reference to the person of God, as does Matthew?

The most plausible answer to this question is that $Q$ had what

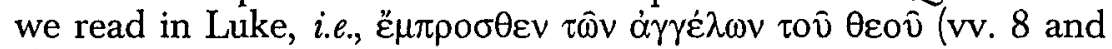
9). Matthew looks upon the reward given by the Son of Man as

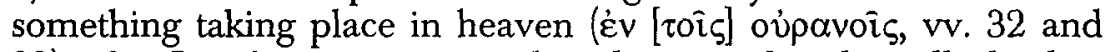
33), after Jesus' resurrection and exaltation, when he will plead in favour of the faithful "before the face of God." A similar idea occurs in Rom 8:34 and Heb 7:25. According to Luke, however, the Son of Man will judge the faithful and the unfaithful on the day of the Last Judgement. At that time he will appear with the angels of God, the angels will form a kind of court, and the Son of Man will sit in judgement upon all people. ${ }^{9}$

It is more probable that the futurist eschatological perspective as presented by Luke was changed to the Matthean perspective of an approval or disapproval in heaven than the other way around. If

${ }^{7}$ C. M. Tuckett, Q and the History of Early Christianity. Studies in Q(Edinburgh 1996), p. 180, n. 50.

${ }^{8}$ See the Appendix to this contribution. To the eleven instances of redactional "the Father in heaven" mentioned there, seven instances of redactional "your (or my) heavenly Father" can be added $(5: 48 ; 6: 14,26,32 ; 15: 13 ; 18: 35 ; 23: 9)$.

For the Son of Man manifesting himself as the eschatological Judge (not as an advocate in heaven, as in Matt 10:32-33; Rom 8:34, and Heb 7:25), see also Mark $10: 37 ; 13: 26-27 ; 14: 62$; probably also Mark 8:38. Furthermore $Q 17: 24,26,30$. 
this is correct, Luke's eschatological view of the Last Judgement in the future, with angels forming a court, must be that of $Q$. But in the framework of that eschatological view angels had a more or less fixed place, determined by tradition. See, for instance, 1 Enoch 62:9-11: when the Son of Man appears on the Day of Judgement, he will be accompanied by "the angels of punishment" who will punish the sinners and lawless; 4 Ezra 13:52: the Son of Man will come together with "those qui cum eo sunt," that is, with the angels; ${ }^{10}$ 1 Thess 3:13: Jesus will come "with all his saints", that is, with the angels or the righteous ones turned into heavenly beings; Mark 13:26 "the Son of Man will come with power... and he will send out the angels." "Thus, there is a strong traditio-historical justification for taking Luke's reading "before the angels of God" as the text of $Q$. This conclusion is valid both for $Q 12: 8$ and for 12:9. In 15:10 Luke used the phrase "before the angels of God" once again, probably under the influence of the wording of Luke/Q 12:8-9, but on his own initiative and without a written source. ${ }^{12}$ For the parable of the Lost Coin (Luke 15:8-10) shows all signs of being Luke's own creation. ${ }^{13}$ It is a Lucan duplicate of the preceding parable of the Lost Sheep which Luke took over from $Q$.

${ }^{10}$ In 4 Ezra (= 2 Esdr) 13 the Son of Man is designated as "Man," in Latin homo (vv. 3, 5, and 12) and vir (vv. 25 and 32). It is not impossible to understand this homo and vir as correct renderings of the Hebrew or Aramaic phrase "Son of Man."

${ }^{11}$ See also Rev 3:5: "I will confess your name before my Father and before his angels." But the possibility that this passage is influenced by the synoptic tradition cannot be ruled out. Moreover, the scene of $\operatorname{Rev} 3: 5$ is in heaven, not on earth at the end of time.

${ }^{12}$ In 15:10, however, "before the angels of God" means "in heaven," not "at the Last Judgement"; see Luke 15:7. The difference in meaning shows that 15:10 represents another, and probably a more recent, stage of the genesis of Luke's gospel than 12:8-9.

${ }^{13}$ The main person in the parable of the lost coin, which occurs only in Luke, is a woman, whereas the main person in the preceding parable (the lost sheep) is a man. Luke likes to present pairs of a man and a woman: Zechariah and Elisabeth (1:5-80); Simeon and Anna (2:22-38); the possessed man in the synagogue of Capernaum and Simon's mother-in-law (4:31-39); the centurion of Capernaum and the widow of Nain (7:1-17); the crippled woman and the man with dropsy $(13: 10-17 ; 14: 1-6)$; the pompous pharisees and the poor widow $(20: 45-21: 4)$; the man with the withered hand and the crippled woman, both healed by Jesus in a synagogue on the sabbath (6:6-11 and 13:10-17); Ananias and Sapphira (Acts 5:111); Aeneas and Dorcas (Acts 9:32-43); Dionysius and Damaris (Acts 17:34); etc. 
Q 12:8b and $9 \mathrm{~b}$ probably had "the angels of God" ( $\tau \hat{\omega} \mathrm{v} \dot{\alpha} \gamma \gamma \dot{\varepsilon} \lambda \omega \mathrm{v}$

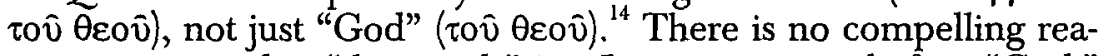
son to assume that "the angels" is a Lucan insertion before "God." Firstly, the mention of a court of "the angels of God," in the midst of which the Son of Man will sit in judgement upon all people at the Last Judgement, makes perfect sense, not only in the context of Luke 12:8-9, but also in that of Q 12:8-9.

Secondly, if $Q$ contained "God," not "the angels of God," the wording of $Q$ would have been quite acceptable to Luke. He probably would not have felt the need to change it. See, for example, Luke 1:15: "he will be great in the sight of the Lord (غ̇vómıov кupiov)"; 12:6 (in the immediate context of our passage 12:8-9):

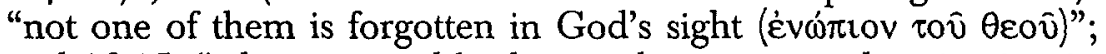
and 16:15: "what is prized by human beings is an abomination in

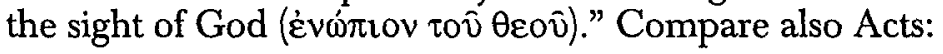

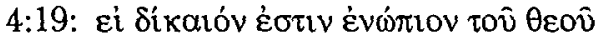

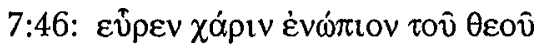

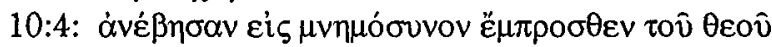

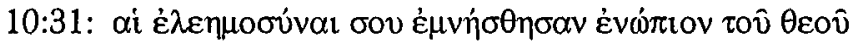

Thirdly, in 12:6 Luke left Q's $\tau 0 \hat{v} \theta \varepsilon \circ \hat{v}$ unchanged, although the evangelist himself replaced the preposition övev (cf. Matt 10:29

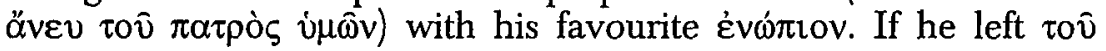
$\theta \varepsilon o v$ unchanged in 12:6, why would he have changed it in 12:8?

Fourthly, in 12:8a and $8 \mathrm{~b}$ Luke took over the preposition $\varepsilon$ z $\mu$ $\pi \rho \circ \sigma \theta \varepsilon v$ from $Q$, in defiance of his strong preference for $\dot{\varepsilon} v \omega ́ \pi \imath$ This may be an indication that he refrained from interfering in the concluding words of v. 8b at all and that he took over $\tau \hat{\omega} v \dot{\alpha} \gamma \gamma \dot{\varepsilon} \lambda \omega v$

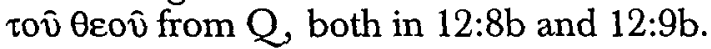

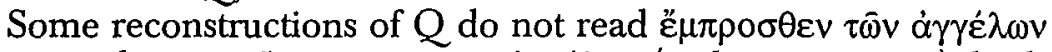

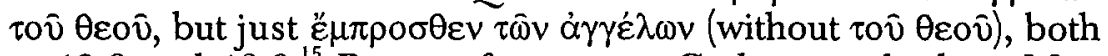
in 12:8 and 12:9. ${ }^{15}$ But a reference to God occurs both in Matt

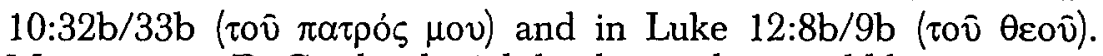
Moreover, as D. Catchpole rightly observed, it would be surprising

\footnotetext{
${ }^{14}$ Here I agree with, inter alios, S. Schula, @ Die Spruchquelle der Evangelisten (Zürich 1972), p. 68, contra W. Schenk, Synopse zur Redenquelle der Evangelien (Düsseldorf 1981), p. 86.

${ }^{15}$ E.g., Fleddermann, Mark and Q pp. 147, 150. His arguments (p. 147, n. 56) are unconvincing.
} 
if Luke had replaced God with the angels. ${ }^{16}$ Luke's $\tau o v$ orov can therefore best be ascribed to $Q$, both in $12: 8 \mathrm{~b}$ and in $12: 9 \mathrm{~b}$.

In all probability, then, the whole phrase $\varepsilon \mu \pi \rho \circ \sigma \theta \varepsilon v \tau \omega \mathrm{\omega} v$

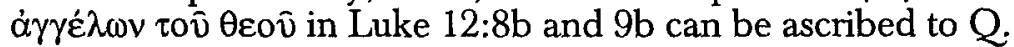

In 12:9b Luke uses the passive $\dot{\alpha} \pi \alpha \rho \vee \eta \theta \dot{\eta} \sigma \varepsilon \tau \alpha l$ with the person denying Jesus as subject, not (as one would expect on the analogy

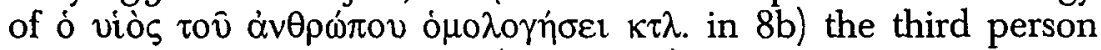

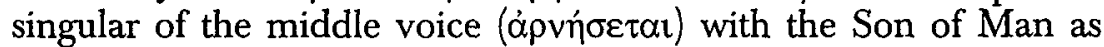
subject. The change of voice can be attributed to Luke, who often avoids repetition and likes stylistic variation. ${ }^{17}$ Moreover, Luke's preference for the future passive is well-known from other passages. ${ }^{18}$ In the present case he did not just change the middle voice to the passive voice, he also switched from the simple $\alpha \rho v \eta$ - to the compound $\alpha \pi \alpha \rho v \eta$. All this is characteristic of Luke. He likes to lengthen the forms of the future passive by prefixes. ${ }^{19} \mathrm{He}$ also likes to change simple verbs in his sources to compound verbs.

Finally, it can be observed that Évórtov, which Luke uses twice in v. 9 where Matthew has $\varepsilon \mu \pi \rho \circ \sigma \theta \varepsilon v$, is very characteristic of Luke's style. ${ }^{21}$ In both cases it is Matthew who preserves the wording of $Q$.

In sum, the $Q$ text of the saying on confessing and denying Jesus may have read as follows:

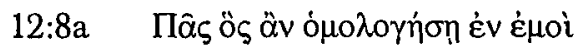
$\ddot{\varepsilon} \mu \pi \rho \circ \sigma \theta \varepsilon v \tau \hat{\omega} v \dot{\alpha} v \theta \rho \omega \dot{\pi} \pi \omega v$,

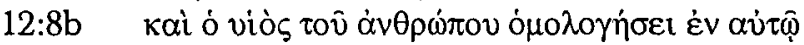

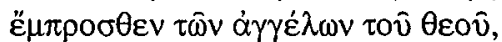

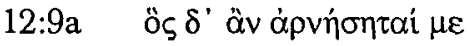
$\ddot{\varepsilon} \mu \pi \rho \circ \sigma \theta \varepsilon v \tau \omega \hat{\omega} v \dot{\alpha} v \theta \rho \omega \dot{\pi} \pi \omega v$,

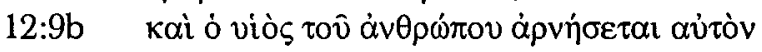

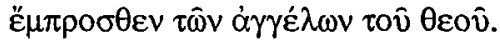

${ }^{16}$ D. R. Catchpole, "The Angelic Son of Man in Luke 12:8," NovT24 (1982), pp. 255-265; see p. 256.

${ }^{17}$ H. J. Cadbury, The Style and Literary Method of Luke (Cambridge [Massachusetts] 1920), p. 83.

${ }^{18}$ Cadbury, Style, p. 164

${ }^{19}$ Cadbury, Style, p. 166.

${ }^{20}$ Cadbury, Style, p. 166.

${ }^{21}$ J. C. Hawkins, Horae synopticae (Oxford $1909^{2}$ ), p. 18 (asterisked; the word does not occur at all in Matt or Mark, 22 times in Luke, and 13 times in Acts). 
This reconstruction agrees entirely with that of $\mathrm{R}$. Pesch, ${ }^{22}$ except that, according to Pesch, the saying of $12: 8 \mathrm{a}$ in $\mathrm{Q}$ was preceded by the formula $\dot{\alpha} \mu \grave{\eta} \nu \lambda \dot{\varepsilon} \gamma \omega \dot{v} \mu \hat{\imath} v$.

\section{Is Luke's rewriting of Q 12:8-9 dependent upon Mark?}

Here we are not broaching an entirely new question. To a considerable extent the question has already been settled when we established the textual form of $Q 12: 8-9$. As soon as one decides that

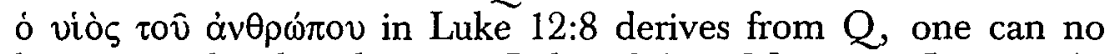
longer ascribe the phrase in Luke 12:8 to Marcan influence. As soon as one decides that ôs öv in Luke 12:8 derives from $Q$ 12:8, one can no longer attribute the phrase to the influence of Mark 8:38. In a way, then, the question of whether Luke 12:8-9 is dependent on Mark has been treated in the previous section.

Yet a further discussion of the question is not wholly superfluous. Firstly, it is almost generally agreed, for instance, that $\beta \lambda \alpha \sigma-$ $\phi \eta \mu \eta \dot{\sigma o v} \tau \imath$ in the next verse, Luke 12:10, is due to the influence of Mark 3:29 on Luke's reworking of $Q$ 12:10. Consequently, the suspicion that something similar is the case in Luke 12:8-9 is not unjustified. Luke 12:8-9 may contain traces of Marcan influence from other passages than Mark 8:38. Secondly, the question of Marcan influence on Luke 12:8-9 deserves to be looked at somewhat more systematically. "The possibility that Luke adapted 12:8a to Mark $8: 38 \mathrm{a}$ " is also taken into consideration by R. Pesch, and rightly so.

Let us begin by listing the distinctive readings of Luke 12:8-9 as compared with $Q$.

\begin{tabular}{|c|c|c|}
\hline & $\ell$ & Luke's redaction in $12: 8-9$ \\
\hline $12: 8 \mathrm{a}$ & & praemittit $\lambda \dot{\varepsilon} \gamma \omega \delta \dot{\varepsilon} \dot{v} \mu \bar{\imath} \nu$ \\
\hline $9 a$ & 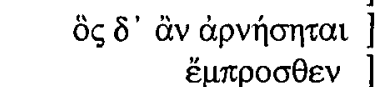 & 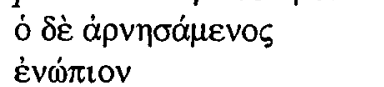 \\
\hline $9 b$ & 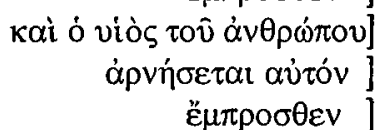 & 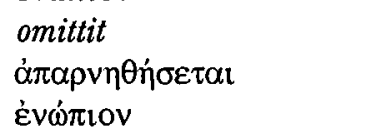 \\
\hline
\end{tabular}

Of these six instances of Lucan redaction in 12:8-9, none shows the influence of Mark 8:38. Some authors have rightly observed,

\footnotetext{
${ }^{22}$ Pesch, "Autorität," p. 30.

${ }^{23}$ Pesch, "Autorität," p. 28.
} 
however, that $\lambda \dot{\varepsilon} \gamma \omega \delta \dot{\varepsilon} \dot{v} \mu \bar{\imath} v$ in 12:8a may be derived from Mark $3: 28{ }^{24}$ While redacting 12:2-10, Luke certainly had the Marcan saying on sinning against the Holy Spirit (Mark 3:28-30) in mind. This is clear from the fact that, as mentioned above, Luke's $\beta \lambda \alpha \sigma-$ $\phi \eta \mu \eta \dot{\sigma o v} \tau \mathrm{r}$ in $12: 10$ is an echo of Mark 3:28-29 (v. $28 \beta \lambda \alpha \sigma$ -



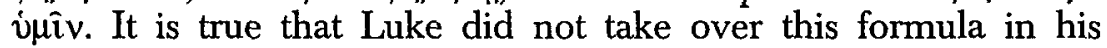
corresponding verse 12:10, but he had a reason for this. Luke wanted to create a close connection between his version of the $Q$ saying on sinning against the Holy Spirit (12:10) and the sayings on confessing and denying (12:8-9). He made a new unit out of the combination of vv. 8-9 and v. 10 by linking v. 10 to vv. 8-9 with a redactional $\kappa a i$. The result is a parallelism between v. 8 and

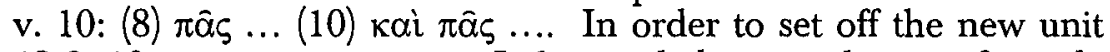
12:8-10 against its context, Luke used the introductory formula

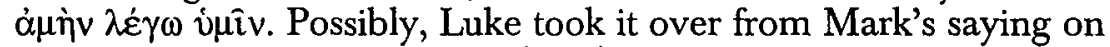
sinning against the Holy Spirit (3:28), a passage omitted by Luke in favour of $Q 12: 10$. In conformity with his own style he dropped $\dot{\alpha} \mu \eta^{25}$ and inserted $\delta \dot{\varepsilon}$. Here, then, we have a possible instance of Marcan influence on Luke's redaction of 12:8.

Yet reasonableness compells us to admit that Marcan influence in the case of $\lambda \dot{\varepsilon} \gamma \omega$ v $\mu \bar{\imath} v$ is just a good possibility. It should be remembered that the formula $\lambda \dot{\varepsilon} \gamma \omega$ i $\mu \bar{i} v$ could be prefixed to sayings of Jesus by anybody transmitting the Lord's teaching. At least some cases of $\lambda \dot{\varepsilon} \gamma \omega$ i $\mu \hat{\imath} v$ in Luke are likely to have been added to the $Q$ material by Luke himself. ${ }^{26}$ Since Luke inserted

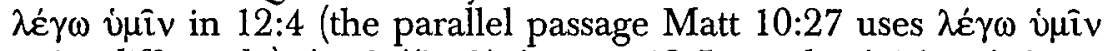

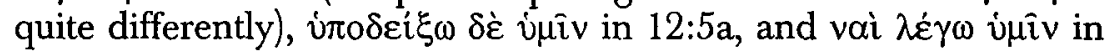
$12: 5 \mathrm{~b}$, one cannot rule out the possibility that $\lambda \dot{\varepsilon} \gamma \omega \delta \dot{\varepsilon} \dot{\nu} \mu \bar{\imath} v$ in $12: 8 \mathrm{a}$ is also due to Luke's own initiative, without any influence from Mark 3:28. Luke seems to use the $\lambda \dot{\varepsilon} \gamma \omega$ í $\mu \hat{\imath} \nu$ formula to impose structure upon 12:2-10. Consequently, the influence of Mark 3:28 on $\lambda \dot{\varepsilon} \gamma \omega$ نे $\mu \bar{\imath} v$ in Luke 12:8 is not certain.

24 H. Schürmann, "Sprachliche Reminiszenzen an abgeänderte oder ausgelassene Bestandteile der Spruchsammlung im Lukas- und Matthäusevangelium," NTS 6 (1959/60), pp. 193-210, esp. 195-199; K. Berger, Die Amen-Worte Jesu, BZNW 39 (Berlin 1970), p. 36: "Der Amen-Einleitung [in Mark 3:28]

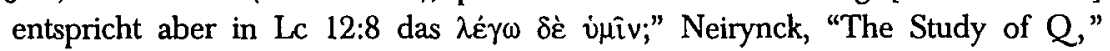
Evangelica, Vol. 2, p. 442.

${ }^{25}$ Cadbury, Style, p. 157.

${ }^{26}$ Neirynck, "The Study of Q," Evangelica, Vol. 2, p. 444. 
The other redactional changes Luke made in 12:8-9, however, do not seem to reflect Mark's influence at all. Once again, all depends here on one's reconstruction of $Q$. In his recent study of Marcan influences on the redaction of Luke 9:51-18:14 (Luke's "great intercalation"), F. Noël has duly recorded H. J. Holtzmann's assessment of the phrase ó viò $\tau$ ỗ $\dot{\alpha} v \theta \rho \omega \dot{\pi}$ ov in Luke 12:8. ${ }^{27}$ According to Holtzmann, ${ }^{28}$ it cannot be ascertained whether ò viòs

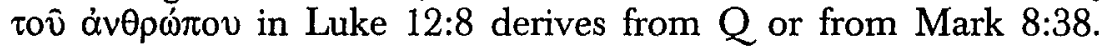
The possibility that it is a reminiscence of Mark 8:38 cannot be ruled out. But, as we argued above, it is more plausible that ó viòs

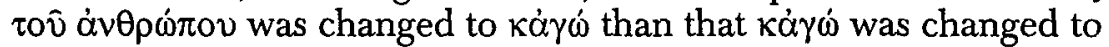

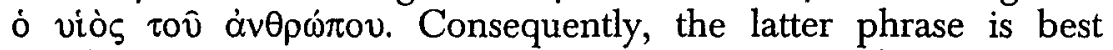
ascribed to $Q$, not to Marcan influence on Luke's redaction.

Noël himself, ${ }^{29}$ in contradistinction to Holtzmann, ${ }^{30}$ reckoned with the possibility that $\tau \hat{\omega} v \dot{\alpha} \gamma \gamma \dot{\varepsilon} \lambda \omega v$ in Luke 12:8 and 9 betrays the influence of Mark 8:38. These angels, however, belong to the traditional scenario of the appearance of the Son of Man (see above). As a result the reference to the angels does not need to be denied to $Q 12: 8-9$. In the case of $\tau \hat{\omega} v$ a $\gamma \gamma \varepsilon \dot{\varepsilon} \lambda \omega v$, too, the supposition of Marcan influence is superfluous.

${ }^{27}$ Filip Noël, Van Marcus tot Lucas. De "grote weglating" (Mc 6,45-8,26) en de "grote inlassing" (LC 9,51-18,14) in de compositie van het Lucasevangelie (unpublished Ph.D. dissertation, Louvain [supervisor A. Denaux]; Louvain 1996), pp. 129, 176.

${ }^{28}$ H.J. Holtzmann, Die synoptischen Evangelien (Leipzig 1863), p. 229.

${ }^{29}$ Noël, Van Marcus tot Lucas, p. 176, ad Luke 12:8-9, second line.

${ }^{30}$ In his Die Synoptiker, Hand-Commentar zum Neuen Testament I.1 (Tübingen/ Leipzig $1901^{3}$ ), p. 235 , Holtzmann rather seems to rule out the possibility that "the angels" of Luke 12:8-9 are due to Marcan influence on Luke's redaction, for here he calls Matthew's repeated "before my Father in heaven" (12:32-33) "specifisch matthäisch." In Die synoptischen Evangelien, p. 183, too, Holtzmann says: "den Engeln Gottes [of the Sayings Source] ist [in Matt 10:] 32. 33 das Angesicht Gottes substituiert." If Holtzmann understood "before my Father in heaven" in Matt 10:32 and 33 as being Matthew's substitute of "before the angels of God" in $Q$, then he must have regarded "before the angels of God" in Luke 12:8 and 9 as deriving from $Q$. In that case, however, he cannot have supposed that "the angels of God" in Luke 12:8 and 9 goes back to Mark. True, in Synoptiker, p. 370, Holtzmann notices: "anstatt der Beziehung auf Gottes Angesicht Mt [10:] 3233 erscheinen Lc [12:] 8 und 9 die Engel Gottes." But this observation intends only to record the discrepancy between Matthew and Luke. It does not intend to say that Matthew retained the $Q$ reading and that Luke changed it, whether or not under the influence of Mark. 
All in all, then, Mark's influence on Luke 12:8-9 seems to be limited to the insertion of the introductory phrase $\lambda \dot{\varepsilon} \gamma \omega \delta \dot{\varepsilon}$ i $\mu \hat{\imath} v$ in v. 8 ( $\delta \varepsilon$ is Lucan redaction; see above) and even in that case Mark's influence remains uncertain.

\section{Is Mark 8:38 dependent on Q 12:8-9?}

Recently, this question has been answered affirmatively by $\mathrm{J}$. Lambrecht ${ }^{31}$ and $H$. T. Fleddermann. ${ }^{32}$ We shall first put $Q$ 12:9 and Mark 8:38 side by side and underline what they have in common. Mark has no parallel to Q 12:8.

$$
\text { Q12:9 }
$$

\begin{tabular}{|c|c|}
\hline $9 \mathrm{a}$ & 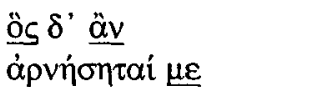 \\
\hline & $\begin{array}{l}\ddot{\varepsilon} \mu \pi \rho \circ \sigma \theta \varepsilon v \\
\tau \hat{\omega} v \dot{\alpha} v \theta \rho \omega \dot{\pi} \pi \omega v\end{array}$ \\
\hline $9 b$ & $\underline{\kappa \alpha i}$ \\
\hline & 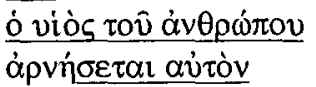 \\
\hline
\end{tabular}

$\ddot{\varepsilon} \mu \pi \rho \circ \sigma \theta \varepsilon v$

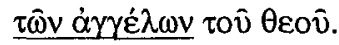

Mark 8:38

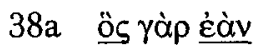
$\dot{\varepsilon} \pi \alpha t \sigma \chi v \vee \theta \hat{n} \mu \varepsilon$

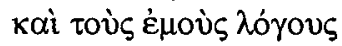

$\dot{\varepsilon} v$

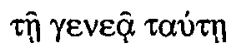
$\tau \hat{n} \mu \circ \imath \chi \alpha \lambda i \delta \imath \kappa \alpha i \dot{\alpha} \mu \alpha \rho \tau \omega \lambda \hat{\omega}$

$38 \mathrm{~b}$ kai

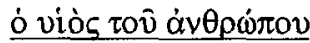

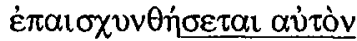
ö $\tau \alpha v \ddot{\varepsilon} \lambda \theta n$

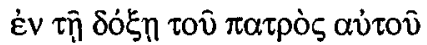
$\mu \varepsilon \tau \grave{\alpha}$

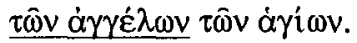

The thematic and syntactic parallelism between $Q 12: 9$ and Mark 8:38 is striking, and although the verbal agreements are not very impressive, they are not lacking. The two passages must be related in some manner. But in order to demonstrate that Mark used $Q$, it does not suffice to refer to the agreements between the two. Mark can only be proven to be dependent on $Q$ if his text can be shown to be dependent on $Q$ 's redaction. $Q$, then, has the following words and phrases in common with Mark 8:38:

${ }^{31}$ J. Lambrecht, "Q-Influence on Mark 8,34-9,1," Logia. Les paroles de Jésus-The Sayings of Jesus. Mémorial Joseph Coppens, ed. J. Delobel, BEThL 59 (Louvain 1982), pp. 277-304, esp. 285-288.

Fleddermann, Mark and $Q$ pp. 145-151. 


\section{Q12:9}

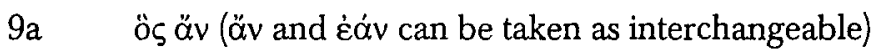

$\mu \grave{\varepsilon}$

$9 \mathrm{~b} \quad$ k $\alpha \mathrm{i}$

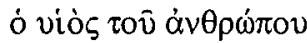

a future indicative verb in the $3^{\text {rd }}$ pers. sing. $+\alpha$ tóv $\tau \hat{\omega} v \dot{\alpha} \gamma \gamma \varepsilon \dot{\lambda} \omega \nu$

None of these words and phrases of $Q$ can be regarded as redactional or as characteristic of Q's style.

Lambrecht points to several elements in Mark 8:38 that, in his opinion, show that Mark is "clearly dependent on Q." At most, however, he has succeeded in showing that, in many respects, the saying on denying Jesus as transmitted in Mark 8:38 represents a later stage of the tradition than does the saying as preserved in $Q$. Unfortunately, Lambrecht does not try to demonstrate that Mark 8:38 is dependent on the redaction of $Q 12: 9$. Consequently, his conclusion that "there is no need to postulate a source other than $Q^{\prime 34}$ seems to be premature.

Fleddermann argues that the $Q$ saying on denying Jesus fits seamlessly in the overall $Q$ portrayal of the Son of Man. Since it fits so smoothly in Q's Christology, the saying could well come from the $Q$ redactor. If so, the saying shows that Mark knew redactional $Q .{ }^{35}$

This line of reasoning, however, cuts no ice. Firstly, it does not follow from the fact that the image of the Son of Man given in $Q$ 12:9 fits smoothly in Q's Christology, that Q 12:9 belongs to the $Q$ redaction. Secondly, the $Q$ saying on sinning against the Holy Spirit $(12: 10)$ has to be regarded as a redactional commentary appended to the saying on denying Jesus, as I shall argue presently. The inconsistency between 12:9 and 12:10 rules out the possibility that $Q 12: 10$ and 12:9 come from the same redactor. $Q 12: 9$ must be regarded, therefore, as pre-redactional. ${ }^{36}$

\footnotetext{
${ }_{34}^{33} \mathrm{~J}$. Lambrecht, "Q-Influence on Mark," p. 287.

${ }^{34}$ Lambrecht, "Q-Influence on Mark," p. 287.

${ }^{35}$ Fleddermann, Mark and Q, p. 151.

${ }^{36}$ H. T. Wrege, "Zur Rolle des Geisteswortes in frühchristlichen Traditionen," Logia, ed. J. Delobel, BEThL 59 (Louvain 1982), pp. 373-377, esp. 374; C. M. Tuckett, "The Son of Man in Q," From Jesus to John (Festschrift M. de Jonge), ed. M. C. de Boer, JSNT.S 84 (Sheffield 1993), pp. 196-215, esp. 211; idem, Q and the
} 
Verse 12:9 asserts that denying Jesus will entail one's perdition at the Last Judgement. Verse 12:10, however, promises that everyone who speaks a word against the Son of Man will be forgiven; only blasphemy against the Holy Spirit will be unforgivable. Obviously, 12:10 intends to add an escape clause to the strict rule of 12:9. Moreover, 12:10 pretends that the phrase "the Son of Man" in 12:9 refers only to the pre-Easter Jesus: those who failed to acknowledge him before Easter may still convert after Easter and be saved. But those who continue to oppose the Holy Spirit after Easter by refusing to convert and confess Jesus, will not be able to be forgiven anymore and cannot be saved.

There can be little doubt that $Q 12: 10$ is a correction of, and a commentary on, the contents of 12:9. If so, 12:9 was written by an earlier hand than 12:10. Q 12:9 does not belong to the final redaction of $\mathrm{Q}$. Consequently, Mark 8:38 has not been proven to be dependent on $Q$ 12:9.

\section{Conclusion}

From the above it can be inferred that $Q 12: 9$ and Mark 8:38 go back independently to a common earlier tradition. It is clear that Q 12:9 preserves this tradition more faithfully than Mark 8:38. Mark's version of the saying betrays many unmistakable signs of Mark's redactional hand:

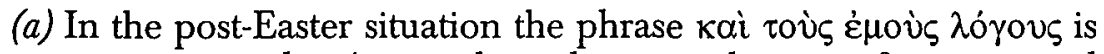
synonymous with $\mu \varepsilon^{\prime}$; together, the two elements form ${ }_{37}$ a good example of the principal hallmark of Mark's style, duality.

(b) Duality also results from the juxtaposition of $\mu \circ \chi \alpha \alpha \lambda i \delta \mathrm{r}$ and $\dot{\alpha} \mu \alpha \rho \tau \omega \lambda \hat{\omega}$.

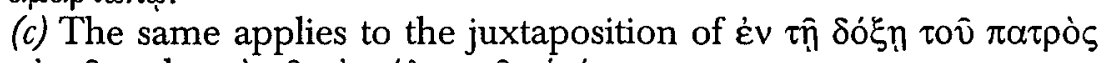

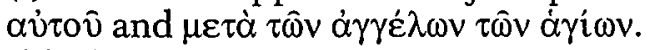

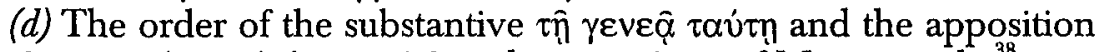

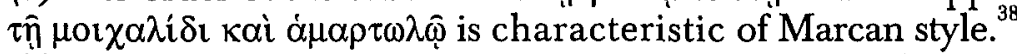

(e) Finally, the multiplication of forms of cognate verbs or of the

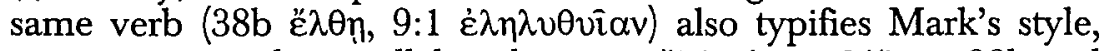

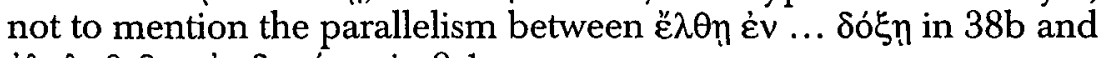

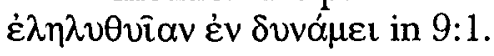

History of Early Christianity, pp. 239-282, esp. 249-250; F. Neirynck, "Assessment," in Fleddermann, Mark and $Q$ pp. 284-285.

${ }^{37}$ F. Neirynck, Duality in Mark, BEThL 31 (revised edition; Louvain 1988), p. 104.

${ }^{38}$ Neirynck, Duality, p. 107. 
Words and phrases in Mark 8:38 that raise the suspicion of

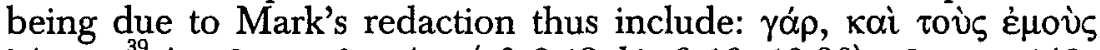

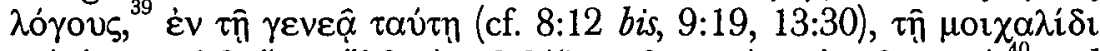

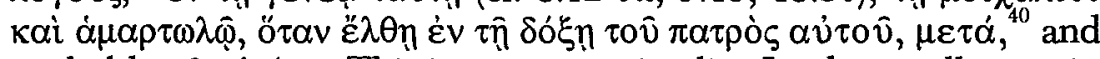
probably $\tau \hat{\omega} v \dot{\alpha} \gamma \dot{\gamma} \omega \mathrm{v}$. This is an impressive list. In almost all cases in which $Q$ and Mark differ, $Q$ seems to preserve the earlier form of the tradition. It follows that the common tradition behind Mark and $Q$ must have been of this tenor:

Whoever disavows me before men, the Son of Man will also disavow him before the angels of God. ${ }^{41}$

It is impossible to say whether this tradition in its earliest traceable stage was phrased in Greek or in Aramaic. It is equally impossible to say with any certainty whether the saying is of pre- or postEaster origin. To the latter question we shall give some further consideration presently. Here the conclusion can be drawn that $Q$ 12:9 and Mark 8:38 allow us to reconstruct the common earlier tradition of a saying in which Jesus states that whoever disavows him before men in this world, will receive no favourable sentence from the Son of Man at the Last Judgement. In other words, everybody's definitive fate will depend on whether or not one has disavowed Jesus and his call to comply with the demands of God's Kingdom.

In the reconstructed saying, the future Son of Man is looked upon as the Judge who, on God's behalf, will soon pass sentence on all people. He will judge everyone in accordance with the way each individual has reacted to Jesus. This image of the Son of Man as the central figure of the Last Judgement is retained in Mark 8:38 and, via $Q$, in Luke 12:8-9. It was changed by Matthew to the image of Jesus as the heavenly advocate, pleading for the faithful before God, but not for the unfaithful (10:32-33).

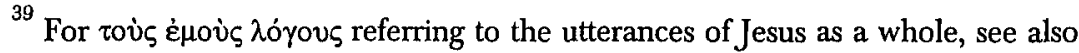
Mark 10:24 and 13:31. At 8:38 the omission of $\lambda$ ó $o v$ s in $W k$ sah is probably due to homoioteleuton.

"After "the Son of Man," this reference to "his Father" is unfortunate and awkward, although understandable in an author for whom Jesus and the Son of Man were entirely identical.

${ }^{41}$ That is, at the Last Judgement. 


\section{Does the primary tradition reconstructed above}

reflect something Jesus himself has said? ${ }^{42}$

It remains true that the distinction between the "me" referring to Jesus and the Son of Man must belong to a very early stage of the tradition. But can we be certain that after Jesus' death none of his followers ever again made a distinction between the persons of the terrestrial Jesus and the coming Son of Man?

We may assume that Jesus convinced a number of sympathizers that his ministry and message marked the turn of the ages. Would such a follower of Jesus, after the Master's death, no longer be able to assert that the Son of Man was to judge each one's fate in accordance with each individual's attitude towards Jesus? And could he not say that Jesus himself had said so? Could no Christian after Easter say that whoever rejected Jesus would have to reckon with his or her condemnation by the Son of Man at the Last Judgement?

Moreover, is it likely that, as long as Jesus and his disciples looked forward to the definitive breakthrough of God's rule on earth, his followers made efforts to remember his words exactly and to transmit them faithfully? Are the recollection, formulation, and transmission of sayings of Jesus not in essence a post-Easter development? If so, how certain can we be that the formulation of such sayings was not affected by the passage of time, the change of situation, the difference in circumstances before and after Jesus' death, new questions, new needs?

On the other hand, it is not absolutely impossible either that at places which Jesus visited as a wandering prophet, his words were remembered or even memorized after he left. His followers and friends can conceivably have cherished the memory of some striking utterance of Jesus and passed it on. With regard to the saying reconstructed above, it cannot be argued that it cannot be preEaster because it focusses on the person of Jesus. It does not focus on Jesus, but on each individual's reaction to Jesus: this reaction will turn out to be decisive for each one's fate at the Last Judgement.

All in all, however, we can neither be sure that the common tradition behind $Q$ 12:9 and Mark 8:38 reaches back to Jesus before Easter, nor that it does not. ${ }^{43}$

42 For a survey of arguments pro and con, none of them compelling, see R. Pesch, "Autorität," pp. 39-41.

${ }^{43}$ It is true that normally, if a passage admits of a satisfactory explanation on a more recent level, an explanation on an earlier level is superfluous. For methodical 
But does this really matter? True, it cannot be ascertained whether the saying underlying Q 12:8 and Mark 8:38 goes back to Jesus. If it does, it can still not be ascertained whether Jesus wanted to suggest that he would turn out to be identical with the Son of Man or that he expected the Son of Man to be someone else. Neither can the possibility be ruled out that he wanted to suggest that he would appear to be the Son of Man. In spite of all our ignorance, however, there can be little doubt that the saying underlying $Q$ 12:8 and Mark 8:38 renders correctly Jesus' view of the importance of his mission, no matter whether or not the saying is his.

Jesus regarded himself as God's final envoy whose task was to announce and inaugurate God's Kingdom and to summon his hearers to repentance, conversion, and radical obedience to God's will. Consequently, he must have been convinced that those who refused to acknowledge him and his message could not be saved when God's reign would manifest itself definitively and the Last Judgement would take place. Jesus also shared the belief that, at the crucial moment, the Son of Man would manifest himself and play a central role in the final Judgement.

The saying underlying $Q$ 12:8 and Mark 8:38 thus reflects faithfully Jesus' assessment of the significance of his own role in the realization of God's plan. Anybody who refused to acknowledge this role by not answering adequately to the demands of God's Kingdom, would perish in the Last Judgement. This belief in the correspondence between one's reaction to Jesus and one's ultimate fate fits just as well in a pre-Easter as in a post-Easter context. No matter whether or not the reconstructed saying is authentic, no matter what its date, its contents and message fit just as well in a situation before Jesus' death as after it.

reasons, given with the "razor of Occam," an explanation on the earlier level should then be excluded. In the case of the reconstructed saying at issue, however, an explanation on the earlier, i.e., the pre-Easter, level must not be ruled out. The reason is that the distinction the saying makes between Jesus and the Son of Man gives it an extraordinarily primitive complexion. The question arises, therefore, whether in the light of the striking primitiveness of the saying, an explanation on a post-Easter level is really sufficiently satisfactory. Since this question cannot easily be decided, Occam's razor is inapplicable here and a pre-Easter origin cannot be excluded. N.B.: This does not mean that a pre-Easter origin is more probable than a post-Easter origin. Neither is "pre-Easter" the same as "spoken by Jesus." 


\section{APPENDIX}

\section{Note on the text of Matt $10: 32$ and 33}

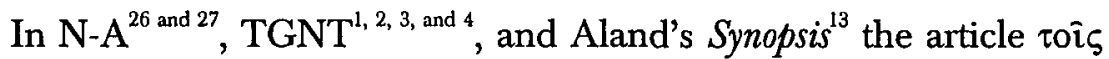
in Matt 10:32 and 33 is printed in square brackets. The brackets indicate that the editors involved were not sure whether or not the article belonged to Matthew's text. In all Nestle and N-A editions from the $1^{\text {st }}$ to the $25^{\text {th }}$, both articles were printed without brackets. In my view the word should probably be omitted from the text and relegated to the apparatus in both cases.

Apart from 10:32-33, Matthew has eleven instances of a

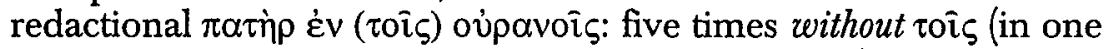
of these cases the longer reading occurs as a variant) and six times with tois (in three of these cases the shorter reading occurs as a variant). The distribution of cases with, and those without rois shows a clear and interesting pattern. In all five instances of the shorter reading, "Father" is in the genitive $(5: 45 ; 12: 50 ; 18: 10$; $18: 14 ; 18: 19)$. In all instances of the longer reading "Father" is in another case than the genitive, either the nominative, or the vocative, dative or accusative $(5: 16 ; 6: 1 ; 6: 9 ; 7: 11 ; 16: 17)$, except in $7: 21$ where "Father" is in the genitive. But here the shorter reading occurs as a variant.

It may be concluded that in Matt 10:32-33, where "Father" is in the genitive, the shorter reading (without $\tau 0 \hat{\imath} \varsigma$ ) is probably to be preferred. The insertion of the article can be explained in terms of improvement of style. The shorter reading is indeed the one adopted by Griesbach $\left(1786^{2}\right)$, C. F. Matthaei $\left(1788^{1} ; 1803^{2}\right)$, Tischendorf in his Octava maior (1869), Von Soden (1913), Vogels (1922; $\left.1955^{4}\right)$, and Bover $\left(1943 ; 1968^{5}\right)$. H. Greeven, ${ }^{44}$ too, has żv ovंpavoi $\zeta$ in v. 32 as well as v. 33 , in contradistinction to Huck, ${ }^{45}$ who

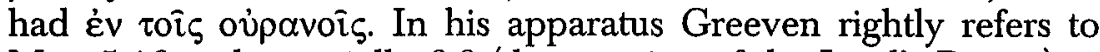
Matt 5:16 and especially 6:9 (the opening of the Lord's Prayer) as well-known passages that may have contributed to the insertion of the article in 10:32 and 33 .

${ }^{44}$ A. Huck and H. Greeven, Synopse der drei ersten Evangelien (Tübingen $1981^{13}$ ), no. 72 , p. 59 .

${ }^{45}$ A. Huck, Synopse der drei ersten Evangelien (Tübingen $1950^{10}$ ). 